\title{
The impact of Cooperative Listening Materials Adaptation on Listening Comprehension Performance of Iranian EFL Learners
}

\author{
Mojtaba Ghassemi ${ }^{1}$ \\ ${ }^{1}$ English Department, University of Khatam, Tehran, Iran \\ Correspondence: Mojtaba Ghassemi, English Dept., Khatam University, Tehran, Iran. Tel: 98-91-2754-3063. \\ E-mail: Ma.Qassemi@gmail.com
}

Received: November 9, 2012 Accepted: November 28, 2012 Online Published: December 26, 2012

doi:10.5539/elt.v6n2p45 URL: http://dx.doi.org/10.5539/elt.v6n2p45

\begin{abstract}
Listening comprehension has gained more prominence in EFL/ESL classes. Due to this prominence, scholars have tried to shed light on different ways of improving learners' listening comprehension. One of these ways is using listening strategies. There is still a controversy over the effective role of these strategies in improving listening comprehension. Thus, the proposed strategies have always been reviewed and reformed. Adopting either strategy, the course shall be quite ineffective if it fails to increase learners' participation in the course. The purpose of this study was to investigate whether or not peer-cooperative self-access materials adaptation has any effect on learners' involvement and participation in listening classes. In addition, the present study tried to probe any possible changes in students' attitude toward listening as a result of the treatment. In order to accomplish the purpose of the study, 90 Iranian students who were studying at Islamic Azad University, an independent university, were selected based on their obtained scores in a language proficiency test (TOEFL). They were randomly assigned to one control and two experimental groups. Then they undertook a 17-session treatment. With a quasi-experimental pretest posttest design, it became evident that having students adapt listening materials improved listening comprehension performance. And also a positive change occurred in students' overall attitude toward listening.
\end{abstract}

Keywords: material adaptation, self-access material, listening comprehension, cooperative adaptation

\section{Introduction}

Not until diminishing prominence of Latin (Richard \& Rodgers, 2001), listening was paid much attention. Emphasizing the important role of listening, researchers argue that learning shall be enhanced through understanding the intended meaning. It is done through processing and perceiving the features of the language and/or transforming data into information (Alalou \& Chamberlain, 1999; Finocchiaro \& Bonomo, 1973; Horton, 2000; Molina, 1997). Thus it would be advisable to consider listening as an integrated part of language classes because developing different modalities of skills like listening provides learners with rich language learning experiences. Otherwise, low listening proficiency may discourage learners to actively participate in oral discussions (Hayati \& jalilfar, 2009). On the other hand, such experiences help learners successfully monitor their own learning (Richards, 2008). In other words, learners will apply the learning strategies including meta-cognitive, cognitive and socio-effective ones to monitor their learning process (Shirini Bidabadi \& Yamat, 2011). Moreover, "See[ing] language in-use" motivates learners through making the language learning setting more interesting (Harmer, 2001. p. 282).

Yet it is rather difficult to encourage learners to involve themselves in listening process as the result of either medium or context (McDonough and Shaw, 1997). One possible solution is to improve learners' attitude through getting them familiar with the process involved (Taylor, 1981).

Such awareness enables learners to apply what they have learnt to improve their language skills not only during but also after the course. This can be achieved only through ensuring that instructional content being developed best suits the students' needs and coordinates foreign language instruction on a campus-wide basis (Branch, 1998; Chaput, 1993; McApline, 1998).

Materials development is a cyclic process that never ends. In a sense, in no stage of this process, one would be sure of the appropriateness of the included materials for a particular group of learners in a particular setting. So, 
the materials should always be revised when it is going to be used in different settings. Tomlinson (2005) argues that most EFL materials are written by well-qualified native-speaker teachers who experienced only small classes with motivated learners. Yet most users of these materials experience EFL in large class of unmotivated learners. In a nutshell, the context is totally different. To solve this problem, Nunan (1993) believes not until we expand students' and teachers' understanding of the processes involved in language learning, we cannot develop appropriate courses. Such understanding brings about consistency among the following variables:

Context (national, regional ...)

Learners (age, language level ...)

Teachers (personality, teaching styles ...)

Materials (text, tasks ...)

Purpose and objectives (course syllabus ...)

(Masuhara, 2004. pp. 1-3)

\subsection{Problem Statement}

Around 50 to 70 percent of the class time is spent on listening; however, it is done ineffectively (Jalongo, 1991; Smith, 1992). Hence teachers' complaint about the lack of instructional materials on listening isn't uncommon (Swanson, 1997). They have been discussing the deficiency of some listening materials available to the teachers and students (Fujiwara, 1996; Rost, 2001). The problem is not just with the importance of teaching the listening skill, but it is with the activities, procedures and materials adopted to approach it. In appropriate listening material, as reported by Yasin Sharif and Ferdous (2012), leads to listening comprehension anxiety.

Empirically, conducting such a study might add to our understanding of the process of listening comprehension. The results of such a study might be of value both to teachers, curriculum designers and even students.

Only that way they can help learners be equipped with listening skill, and consequently enhance their learning via listening (Molina, 1997). Doing so, it is seemingly required to investigate the kinds of Strategies and techniques curriculum designers and material developers can use to help learners improve their listening comprehension.

Since learning material is the core source in any language-teaching/learning program (Richards, 2010), considering these strategies and techniques while designing, they assert, will ensure us that the designed listening materials appeal to learners' personal interest (Brown, 2001; Nunan, 1997). It will sustain attention and positive emotion. cooperatively-adapted (teacher and students) materials not only enjoys high face validity but results also in consistency in gathering of divergent opinions at times convenient to participants; meetings dominated by content not personality; adherence to a structured agenda without loss of those ideas after the session ends (Helten \& Nye, 2005)

Therefore such collaboration in materials adaptation ensures the success of the program. Yet the notion of including the most appropriate materials to meet the lesson objectives, course and leaners' needs is relatively new to the research literature (Tomlinson, 2001). Bearing it in mind, researchers have conducted a number of studies on course design, materials development and strategy training. They hoped they could help learners become independent.

\subsection{Research Questions}

In the present study, listening as a macro-skill as stated by Nunan (1993) and material adaptation (an important stage of curriculum development) are selected as the starting point. Thus material adaptation is intended to attract the students' attention and involve them into the learning program.

Based upon such an assumption, the present study was developed to investigate whether peer self-access material adaptation has any effect on listening comprehension, and whether or not this would change the students' attitude toward listening comprehension. In order to give direction to the study, the following questions were formulated:

Does peer cooperative self-access listening materials adaptation have any effect on genre-based listening comprehension (movies and news) of Iranian EFL learners?

Does peer cooperative self-access listening materials adaptation have any effect on Iranian EFL learners' perception of listening comprehension learning?

These directive questions are trying to touch the aspect of a receptive skill which according to Carkin (2005) 
"lacks the strong background of...literate skills" (p. 114). Such a rather weak background stems from the fact few studies have been carried out on materials development in general and listening materials adaptation inparticular (Bhatia, 1994; Brown, 2001; Fujiwara, 1996; Rashidi \& Safari, 2011; Tomlinson, 2001).

\subsection{Literature Review}

Uvin (1996), in an attempt that led to the development of an ESOL course for Chinese health-care workers, asserts that learners and clients should be actively involved in all stages of course and material development. Doing so would facilitate the learners' participation. To trigger learners' participation, he used two approaches. Problem-posing: here, a situation was described and learners were supposed to react by "discussion, planning, action and feedback" (p. 49). The other approach was experimental learning in which learners' daily experience was used. These approaches, he argues, helped learners attain competencies (sense of ownership, motivation and self-esteem). In addition, class activities became more compatible with preferred learning activities. Materials, he continues, were highly relevant because they were all generated by the learners.

Pinheiro (1996), in a study on designing a writing component, regarded the learners' background. Therefore, she provides the learners with in-class and out-of-class graded activities. Having conducted the study, she argues that such a process may increase learners' interaction or collaboration.

Regarding listening some studies have been done too. Fujiwara (1996), trying to encourage the learners to be more active in the listening class and improve their attitude, involved learners in the process of materials adaptation. She designed listening diary homework. At the end, she, in a survey, found that the learners' attitude toward listening had become more positive and their comprehension had greatly improved.

All the above studies have been carried out to facilitate comprehension performance. However, learners' needs should not lose sight of. In different situations the learners' needs differ from one another. To ensure that these needs will definitely be met those who undertake listening material development need to get familiar with the learners at least through a distributed questionnaire. Collecting such data that way increases the possibility of meeting such needs.

\section{Methodology}

\subsection{Participants}

The study can be categorized as the quasi-experimental pretest posttest control group design. The field work was conducted in Islamic Azad University of Qom where 90 participants (both females and males) were selected based upon their scores on the TOEFL Test (2008). The test was given to 120 students, and from among those who clustered around the total mean, 90 students were selected. 60 students were assigned to the experimental group, which included two subgroups with 30 students each, the remaining 30 students were assigned to the control group. Ages of participants ranged from 20 to 26. They were all senior students studying at their 6th term. They enrolled in a two-credit course on either "Oral translation II" or "Movie translation."

In this study, peer cooperative material adaptation and genre-based listening (news and movies) were considered as independent variables; while, learners' listening comprehension performance and students' attitudes toward listening as the dependent variables.

\subsection{Instruments}

The instruments used in this study include a standardized TOEFL test (adopted from Barron TOEFL 2008), a standardized listening test (TOEFL) used as the "pretest" and "posttest" and a questionnaire. In addition to the major instruments, a teacher's guide and informal observation were also used to control some of the variables, which were supposed to influence validity of the study.

Teacher's guide, the second instrument, was one of the measures taken to ensure teachers were following the same procedures for comparability purposes. As not to offend experienced teachers or overload teachers' minds with details, teachers guide items were formulated as suggestions and attempts were made not to go into details of the steps in different phases of each lesson.

The other measure taken to ensure consistency in handling the treatment was informal observation. The researcher himself attended the classes without prior notice. The purpose was to see if the teachers adhered to the teachers' guide provided by the researcher.

Then, for the pretest, a TOEFL test was administered. Sitting it, the students were required to answer 122 multiple-choice items comprising listening section with 50 items, use of English with 26 items and reading comprehension with 46 items. This test was used to assess both language and listening proficiency level of the learners. 
Posttest was the next instrument used to measure the subjects' achievement after the treatment. In order to probe whether or not there is any change in the listening performance of the learners, a standardized listening test was used. The listening part of the TOEFL test, which was used as the pretest and comprised 50 items was again administered to all three groups.

The questionnaire was the last instrument used in the present study. The questionnaire was organized into three parts. The first part aims at eliciting the demographic information; full name (optional), major, and the participants' study semester. The second part included 20 items. The purpose was to examine the attitude of the respondents towards listening. In this section students' answers were mapped on a five-level Liker Scale (1 indicating "strongly agree" and 5 "strongly disagree"). Finally, in the third section, the respondents" comments were elicited through an open-ended question. The whole items in the questionnaire were categorized into two parts. The firs part measures students' positive attitudes; while the second part negative ones.

\subsection{Data Analysis}

In order to examine the psychometrics of the questionnaire utilized in this study, a pilot study was carried out. To estimate its validity and reliability of the items included, the feedback of three PhD holders in TEFL was collected regarding the suitability (relevance) and clarity of the items included. They were supposed to rate the items in 1-5 rating scale on two feedback forms (one for suitability and the other for clarity).

As table 1 and 2 indicate, the critical value of " $r$ " at 22 degrees of freedom is .43. Since all the computed "rs" are higher than .43, it shows a high degree of agreement among the raters on the relevance and clarity of each item in the questionnaire at the significant level of 0.01 (2-tailed).

Table 1. Spearman Inter-Rater Correlation Co-efficient (Relevance)

\begin{tabular}{lllll}
\hline & & Rater 1 & Rater 2 & Rater 3 \\
\hline Rater 1 & Pearson Correlation & 1 & $.749(* *)$ & $.678(* *)$ \\
\hline Rater 2 & Pearson Correlation & $.749(* *)$ & 1 & $.694(* *)$ \\
\hline Rater 3 & Pearson Correlation & $.678(* *)$ & $.694(* *)$ & 1 \\
\hline
\end{tabular}

Table 2. Spearman Inter-Rater Correlation Co-efficient (Clarity)

\begin{tabular}{lllll}
\hline & & Rater 1 & Rater 2 & Rater 3 \\
\hline Rater 1 & Pearson Correlation & 1.000 & $.806\left(^{* *}\right)$ & $.693(* *)$ \\
\hline Rater 2 & Pearson Correlation & $.806(* *)$ & 1.000 & $.626\left(^{* *}\right)$ \\
\hline Rater 3 & Pearson Correlation & $.693(* *)$ & $.626\left(^{* *}\right)$ & 1.000 \\
\hline
\end{tabular}

Alternatively, an attempt was made to test out the reliability of the questionnaire. In so doing, the questionnaire was administrated to 23 EFL students (15 females and 8 males). The data obtained were fed into the SPSS software to run Cornbach alpha. The results showed that the questionnaire was reliable $(\alpha=0.74)$.

\subsection{Procedure}

In order to carry out the present study, the following steps were followed. First, the TOEFL test was administrated in the first session of the term to serve a two-fold purpose. It was going to measure the general language and listening proficiency level of the students to ensure that all subjects are roughly at the same level of proficiency. Having done it, the homogeneity of the groups was assured.

In case of the homogeneity of the subjects, the test aimed at selecting 90 subjects in the available classes. The 90 subjects were selected from among those whose scores fell one standard deviation above and below the mean. The chosen subjects were then, randomly, assigned to two experimental groups and one control one.

The listening part of the TOEFL test was also used as the pretest. Then the listening part used as pretest was again administrated as the posttest. The purpose was to study the changes that might have occurred in the listening ability of the students. Next, the questionnaire was administered to check the learners' perceptions toward listening. Therefore an attitude questionnaire was used both at the beginning and end of the study.

The experimental groups received the treatment, which consisted of assignments for teaching listening comprehension. The assignments were different from what were the normal teaching procedures used with control group. The control group was basically exposed to listening audio programs, which were played and replayed for comprehension purposes followed by activities focused on language of the texts used for listening.

The experimental groups were exposed to listening materials that are news and movies. The materials were selected by the students themselves. The activities were designed based on model proposed by Brown (2001, see 
pp. 260-264). Following the 17-session treatment, the attitude questionnaire was given to the groups to determine any changes or lack of changes in their attitudes.

Attempts were made over the treatment period to have rather the same condition in all these classes. One way to meet such a criterion was to ask the teachers to accomplish the tasks in accordance with check list provided to them.

In order to check whether the same procedures were used toward the teaching materials and whether the classes were held according to the checklist provided to the teachers, informal observations were conducted. The criteria for observation were those items included in the checklist. This kind of observation showed that all the teachers followed the guidelines in the checklist.

The teacher assumed the role of consultant in the experimental groups. In other words, at the beginning of the experiment, the teacher introduced the criteria needed to be taken into account while adapting listening materials in a briefing session. Then, he was available for consultation at the different stages of the process. On the other hand, the teacher was the only source of information in the control group.

\section{Results and Discussion}

The first statistic was Descriptive to ensure the homogeneity of the groups. It is shown in table 3 .

Table 3. Descriptive Statistics of the scores in the TOEFL test

\begin{tabular}{llll}
\hline $\mathrm{N}$ & $\begin{array}{l}\text { No of } \\
\text { Items }\end{array}$ & Mean & $\mathrm{SD}$ \\
\hline 120 & 122 & 15.4 & 2.04 \\
\hline
\end{tabular}

From among the students whose scores were one standard deviation above and below the mean, 90 students out of 120 were selected. Then, they were randomly assigned to 3 groups (two experimental groups and one control group). Table 4 shows that the mean and variance of the three groups with thirty members each are about the same, so the three groups can be considered as homogenous.

Table 4. Descriptive Statistics of Proficiency test

\begin{tabular}{lllll}
\hline & $\mathrm{N}$ & Mean & Std. Deviation & Variance \\
\hline EXP-G1 (movie) & 30 & 15.02 & 2.04285 & 4.173 \\
\hline EXP-G2 (News) & 30 & 15.35 & 2.04223 & 4.171 \\
\hline Control-G & 30 & 15.08 & 1.99613 & 3.484
\end{tabular}

In order to check listening ability of these three groups, the scores obtained in the listening part of TOEFL were again fed into SPSS. The results are presented in table 5.

Table 5. Descriptive statistics of Listening Proficiency test

\begin{tabular}{lllll}
\hline & $\mathrm{N}$ & Mean & Std. Deviation & Variance \\
\hline Exp-G1(movie) & 30 & 13.95 & 3.09 & 9.60 \\
\hline Exp-G2 (News) & 30 & 13.01 & 3.12 & 9.77 \\
\hline Control G & 30 & 13.63 & 3.41 & 10.60 \\
\hline
\end{tabular}

It can be inferred from the data that the three groups had almost the same Mean and Standard deviation, which indicate the homogeneity of the groups regarding listening ability.

The next attempt was to determine the students' perception toward listening learning before carrying out the treatment. In so doing, the questionnaire was distributed among the subjects. Then, the results obtained from the first administration of the questionnaire were gathered and fed into SPSS. In order to check whether the difference was significant, Chi-Square was run. Table 6 summarizes the results.

Table 6. Chi-Square Statistics for pretest

\begin{tabular}{llll}
\hline Chi-Square Tests & Value & df & Asymp. Sig. (2-sided) \\
& & & \\
\hline Pearson Chi-Square & $138.895(\mathrm{a})$ & 4 & .000 \\
\hline Likelihood Ratio & 143.839 & 4 & .000 \\
\hline Linear-by-Linear Association & 120.582 & 1 & .000 \\
\hline A 0 cells $(.0 \%)$ have expected count less than 5. The minimum expected count is 44.96.
\end{tabular}

The figure shown in table 4 indicates that there is a significant relationship between items measuring positive attitude and those measuring negative attitude. In order to check whether the magnitude of the subjects' tendency 
moves toward positive or negative, a correlation coefficient was run.

Table 7. Spearman' rho correlations of items of questionnaire

POSITIVE NEGATIVE TOTAL

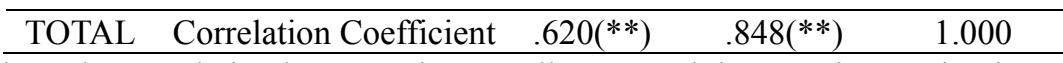

As depicted in table 7, the correlation between the overall score and the negative section is much higher than the correlation between the overall score and the score of the positive section at the significant level of 0.01 . This suggests that the students have an overall negative attitude toward listening.

In order to answer the first research question, the gain score of each student was calculated. Gain scores calculated show 13\% improvement on students' listening achievement. In order to see if there was any significant difference between the mean score of three groups, a One-Way ANOVA was conducted on the gain score. The $\mathrm{P}$ value, at 2 and 87 degree of freedom was smaller than .05 (table 8).

Table 8. The results of One-Way ANOVA for the Gain Score

\begin{tabular}{lllll}
\hline & Sum of Squares & df & F & Sig. \\
\hline Between Groups & 4.83 & 2 & 20.21 & .00 \\
\hline Within Groups & 10.41 & 87 & & \\
\hline
\end{tabular}

The results obtained from running One-Way ANOVA showed that there were significant differences between the mean scores of these three groups. This result does not show where exactly the real differences lie. To find out where the groups were significantly different, a Pos Hoc comparison of means (Tukey) was conducted.

Table 9. The results of Multiple Comparisons (Tukey) for the Posttest

\begin{tabular}{lllllll}
\hline & & $\begin{array}{l}\text { Mean } \\
\text { Difference } \\
(\mathrm{I}-\mathrm{J})\end{array}$ & Std. Error & Sig. & $95 \%$ Confidence Interval \\
& & $.52\left(^{*}\right)$ & .089 & .00 & .73 & .30 \\
\hline \multirow{2}{*}{ Control-G } & Exp-G2 (news) & $.45\left(^{*}\right)$ & .089 & .00 & .66 & .24 \\
\cline { 2 - 7 } & Exp-G1 (Movie) & $.52\left(^{*}\right)$ & .089 & .00 & .30 & .73 \\
\hline \multirow{2}{*}{ Exp-G2 (news) } & Control-G & .06 & .089 & .74 & .14 & .27 \\
\cline { 2 - 7 } & Exp-G1 (Movie) & $.45\left(^{*}\right)$ & .089 & .00 & .24 & .66 \\
\hline \multirow{2}{*}{$\begin{array}{l}\text { Exp-G1 } \\
\text { (Movie) }\end{array}$} & Control & .06 & .089 & .74 & .27 & .14 \\
\cline { 2 - 7 } & Exp-G2 (news) & .069 & \\
\hline
\end{tabular}

As it is shown in Table 9, there is a significant difference at the level of 0.05 between the Control and Experimental (News) and Experimental (Movie). The results also show that there is no difference between the Experimental groups. In order to answer the second research question, the results of the second administration of the attitude questionnaire were fed into SPSS. The results are shown in table 10.

Table 10. Chi-Square Statistics for Posttest

\begin{tabular}{llll}
\hline & Value & df & Asymp. Sig. (2-sided) \\
\hline Pearson Chi-Square & $122.062(\mathrm{a})$ & 4 & .000 \\
\hline Likelihood Ratio & 125.407 & 4 & .000 \\
\hline Linear-by-Linear Association & 105.693 & 1 & .000 \\
\hline
\end{tabular}

According to the results presented in table 10, the difference is significant at alpha level of .05 . To be able to show the attitude direction move clearly, a correlation coefficient was run. The results are summarized in table 11 .

Table 11. The Spearman' rho correlations of items of questionnaire

\begin{tabular}{llllll}
\hline & & & POSITIVE & NEGATIVE & TOTAL \\
\hline Spearman' rho & TOTAL & Correlation Coefficient & $.854(* *)$ & $.565(* *)$ & 1.000 \\
\hline
\end{tabular}

The results show that the correlation found between the positive items and the total number of responses is higher than the correlation between the scores on the negative questions and the total score. The figure 0.85 is much higher than 0.56 , which suggests a positive direction in students' attitude.

The abovementioned results for the first stage of the study indicate that cooperative materials adaptation significantly affected the listening performance of language learners. The reason may be due to the fact that 
adapted listening materials met learners' needs, were interesting to them and consequently increased learners' participation. Subsequently the teacher shall notice an improvement in learners' gain scores. In this study, the subjects in the experimental groups who had the chance to adapt listening materials cooperatively accomplished the tasks assigned better than those in the control group who did not have such an opportunity. It advocates the necessity of involving those who are going to use the listening materials in the process of material use adaptation to ensure meeting meet the true needs of the students (Tomlinson, Dat, Masuhara and Rudby, 2001).

As for the results for the second part of the study, the impact of such a Strategy on changing learners' attitude toward listening was probed. In this study, a positive change occurred in the attitude of learners in experimental groups though the so great. So it may be concluded that the attitude improved as listening materials users were playing an active role in the process of instructional materials development. The reason of such a change might be due to raising learners' awareness, meeting their true needs and cooperative materials adaptation.

The results support the earlier studies done on different aspects of involving learners in the process of learning materials adaptation. Employing a procedure contrary to the most common one (teacher selected material) currently exercised by teachers in teaching listening comprehension, Fujiwara (1996) reported a change in the performance and attitude of those who themselves adapted listening materials. Unlike her subjects who adapted materials in isolation based upon listening diary, the subjects of the present study adapted materials cooperatively from among self-access materials. This strategy proved to encourage learners to be involved in performing in-class and out-class listening activities in order to improve their listening performance. As stated by Tomlinson, Dat, Masuhara and Rudby (2001) and Fujiwara (1996) the benefits achieved through the involvement of learners may be significant provided that such procedure is employed by material designers and teachers.

The findings also support a work by Uvin (1996). He reported that learning would be fascinated through the involvement of the learners into all stages of ESOL course. Like his approach, in this study, problem solving technique (discussion, planning and action) was utilized toward materials adaptation.

Finally the results of the study go in line with a work by Pinheiro (1996). She in her study relied mainly on learners' prior experiences and background while developing the instructional materials. Like her study, the findings show an improvement in compatibility of learning activities. She reported an increase in learners' interaction and collaboration as the results of such compatibility.

Based on such findings peer cooperative self-access material adaptation serves as an enhancer in the process of listening comprehension teaching and development of this skill. This strategy helps the teachers motivate and encourage EFL learners to participate in in-class and out-class listening activities.

Yet it is seemingly required to hold a briefing session during which the major learning issues are introduced and discussed. The general outcome of the session was improving learners' awareness. The second outcome which directly contributes to such an awareness was adaptation of materials which best suited their needs. Marrying up these two and peer cooperation led to high level of participation, interaction, collaboration and ultimately a sense of achievement.

However, there is still a fact that should not be lost sight of. Material adaptation by learners doesn't mean that only learners should undertake material adaptation. What the learners do needs to be supplemented by consultation, assist and support on the part of the teachers. In fact the role of grading listening materials and tasks, which is needed to be carried out only by professionals- material developers, teachers and etc, should not be ignored. The latter is certainly a common procedure particularly used by teachers in listening classes, and it has confirmed to be affective (Nunan, 1993). Nevertheless, the use of learners' involvement as a strategy offers some potential additional advantages to listening comprehension enhancement.

\section{Conclusion and Implications}

Pedagogically speaking, the findings of the present study should modify our understating of nature of materials adaptation. Through adaptation activities, learners not only see the actual use of language but also the input they receive will be enriched culturally (Alalou and Chamberlain, 1999). One thing that debilitates listening comprehension is the lack of EFL learners' participation in the process. An appropriate solution for this problem is the involvement of learners in the process of material adaptation support teachers a lot because first it motivates learners to participate enthusiastically in the listening activities (Hull, 1996). It is just because when they adapt listening materials, the material adapted will be based on their interest. Therefore, they necessarily become fully involved in learning the new language. Second, in their attempts to adapt self-access listening materials, meeting their true needs is guaranteed. Third, it allows the students to be more adventurous with the 
language. This at the end enriches input from cultural point of view.

As a matter of fact, learning and stabilizing a new language through encouraging learners to become involved willingly in listening tasks is one side of the coin. The other one is that teachers and material developers can recognize the problematic areas in listening through the process. Practically, strategic use of peer cooperative self-access material adaptation has positive backwash effect on teaching. In a better sense, teachers can easily notice knowledge gaps and try to remove the obstacles.

This is achieved through letting learners check and probe the available listening materials according to their needs and interests. Meantime, learners should be cooperative and at the same time autonomous. Knowing it, the syllabus designers and material developers along with the teachers can successfully adapt effective listening materials. Thus, it seemingly is the responsibility of the syllabus designers and material developers to involve learners in the process of material adaptation to the extent that their enthusiastic participation increases and as the result learning takes place.

Hopefully, this study is not an ending but the beginning. More research is needed to be done to increase our understanding of how different factors such as different proficiency levels, genres and language skills may affect learners' participation, attitude and consequently performance.

\section{Acknowledgements}

The honorable university professors, my colleagues, students and friends have been of invaluable assistance in the preparation of this research. My debt of gratitude is to Dr. M.R. Anani Sarab whose invaluable cooperation and assistance helped me carry out this project. I am extremely grateful to Dr. M. R. Ataii for providing me nice comments to enrich the project.

\section{References}

Alalou, A., \& Chamberlain, E. (1999). Using Students' Expectations and Perceived Needs to Rethink Pedagogy and Curriculum: a Case Study. Foreign Language Annals, 32(1), 27-45.

Bhatia, V. K. (1994). Analyzing Genre: Language Use in Professional Settings. London: Longman.

Branch, A. M. (1998). Battling the Babel. Yale Alumni Magazine, April Issue, 34- 39.

Brown, D. H. (2001). Teaching by Principle: an Interactive $x$ Teaching to Language Pedagogy (2nd Edition). London: Longman.

Carkin, S. (2005). English for Academic Purposes. In Hinkle, E. (Ed.), Hand Book of Research in Second Language Learning and Teaching. London: Lawrence Erlbaum Association.

Chaput, P. P. (1993). Revitalizing the Traditional Program. In M. Krueger, \& F. Ryan (Eds.), Language and Content: Discipline and Content Based Approaches to Language Study. Lexington, MA: D.C. Heath.

Finocchiaro, M., \& Bonomo, M. (1973). The Foreign Language Learners: a Guide for Teachers. New York: Regents Publishing Company.

Fujiwara, B. (1996). Planning an Advanced Listening Comprehension Elective for Japanese College Students. In K. Graves (Ed.), Teachers as Course Developers (pp. 151-175). New York: Cambridge.

Harmer, J. (2001). The Practice of English Language Teaching. London: Longman.

Hayati, M., \& Jalilfar, A. (2009). The Impact of Note-taking Strategies on Listening Comprehension of EFL Learners. English Language Teaching, 2(1), 101-111.

Helten, M. M., \& Nye, B. J. (2005). E-Learning: Transforming Education Using Collaborative Tools for Assessment and Evaluation. Retrieved from http://www.eric.ed.gov/PDFS/ ED485098.pdf

Horton, William. (2000). Designing web based training. NY: John Wiley \& Sons, Inc.

Jalongo, M. R. (1991). Promoting Active Listening in the Classroom. Children Education, 13-18.

Masuhara, H. (2004). Material Adaptation. In B. Tomlinson, \& H. Masuhara (Eds.), Developing Language Course Materials. Singapore: RELC.

McApline, D. (1998). Restructuring Language Department: Going Down the Rocky Road. ADFL Bulletin, 28(3), 9-10.

McDonough, J., \& Shaw, C. (1997). Material and Method in ELT. Oxford: Blackwell.

Molina, V. (1997). Improving Student Listening Skills Through the Use of Teaching Strategies. Published Master's Thesis, Saint Xavier University. Retrieved from http://www.eric.ed.gov/PDFS/ ED409537.pdf 
Nunan, D. (1993). Syllabus Design. Oxford: Oxford University Press.

Nunan, D. (1997). Listening in Language Learning. Retrieved from http://www.jalt-publications.org/tlt/files/97/sep/nunan.html

Pinheiro, M. E. (1996). Designing a Writing Component for Teen Courses at a Brazilian Language Institute. In K. Graves (Ed.), Teachers as Course Developers (pp. 39-62). New York: Cambridge.

Rashidi, N., \& Safari, F. (2011). A Model for EFL Materials Development withinthe Framework of Critical Pedagogy (CP). English Language Teaching, 4(2), 250-259. http://dx.doi.org/10.5539/elt.v4n2p250

Richards, J. C. (2008). Moving Beyond the Plateau: From Intermediate to Advanced Levels in Language Learning. Cambridge: Cambridge University Press.

Richards, J. C. (2010). Series editor's preface. In N. Harwood (Ed.), English language teaching materials: theory and practice (pp. ix-xi). Cambridge: Cambridge University Press.

Richards, J. C., \& Rodgers, T. (2001). Approaches and Method in Language Teaching. Cambridge: Cambridge University Press.

Rost, M. (2001). Listening. In R. Carter, \& D. Nunan (Eds.), Teaching English to the Speakers of Other Languages. Cambridge: Cambridge University Press.

Shirini Bidabadi, F., \& Yamat, H. (2011). The Relationship between Listening Strategies Used by Iranian EFL Freshman University Students and Their Listening Proficiency Levels. English Language Teaching, 4(1), 26-32.

Smith, Carl. (1992). How can Parents Model good Listening Skills? Retrieved from http://www.eric.ed.gov/PDFS/ED376481.pdf

Swanson, C. R. (1997). Who is Listening in the Classroom? A Research Paradigm. Paper presented at the 16th Annual Meeting of the International Listening Association. Sacramento, CA.

Taylor, H. M. (1981). Learning to Listen to English. TESOL Quarterly, 15(1), 41-50.

Tomlinson, B. (2001). Material Development. In R. Carter, \& D. Nunan, (Ed), Teaching English to the Speakers of Other Languages. Cambridge: Cambridge University Press.

Tomlinson, B. (2005). English as Foreign Language: Matching Procedures to the Context of Learning. In Hinkle, E. (Ed.), Hand Book of Research in Second Language Learning and Teaching. London: Lawrence Erlbaum Association.

Uvin, J. (1996). Designing Workplace ESOL Course for Chinese Health-Care Workers at A Nursing Home. In K. Graves (Ed.), Teachers as Course Developers (pp. 39-62). New York: Cambridge.

Yasin Sharif, M., \& Ferdous, F. (2012). Sources and Suggestions to Lower Listening Comprehension Anxiety in the EFL Classroom: A Case Study. English Language Teaching, 5(10), 92-104. http://dx.doi.org/10.5539/elt.v5n10p92

\section{Appendix}

\section{Questionnaire}

Dear Participants,

Thank you for participating in present survey. We would like to explore the effect of listening materials on the attitude of language learners and consequently on listening performance. Please complete this brief survey about your attitude toward listening skill. The results of the study may lead to an improvement in teaching/learning listening and listening materials adaptation. Your answers will be kept confidential

Major of study (optional): $\quad$ Gender: $\mathrm{M} \square \quad \mathrm{F} \square$

\section{$\underline{\text { Part A }}$}

Please rank your own proficiency level of the following skills on a scale of 1 to 4

( $1=$ highly proficient; 2 = proficient; $3=$ intermediate; $4=$ novice $)$

Listening: ......... Speaking: ........ Reading :....... Writing:......

Please rank the following skills according to your own personal interest in them on the scale of 1 to 4 .

( $1=$ highly interested; $2=$ interested; $3=$ no idea; $4=$ not interested $)$ 
Listening:

Speaking:

Reading

Writing

\section{Part B}

Please circle the number which reflects your opinions as accurately as possible.

( 1 = strongly agree; 2 = agree; $3=$ no idea; $5=$ disagree, $5=$ strongly disagree $)$

1. I enjoy listening to language listening materials.

2. Listening comprehension plays a crucial role in our daily lives.

3. Improving listening comprehension may positive effect on job promotion.

4. I like learning English through listening activities the best.

5. I enjoy doing listening activities.

6. I am satisfied with way listening materials are presented in the class.

7. I easily accomplish listening tasks assigned in the class.

8. I believe listening tasks and activities are highly useful in language classes.

9. I believe listening is the easiest skill to master in language learning.

10. There is enough time allocated to listening tasks in language classes.

11. I always do listening tasks voluntarily in the class.

12. Improving listening skill may lead to the improvement of other language skills.

13. I can't do listening task self-confidently.

14. Due to lack of self-confidence, I avoid doing listening tasks.

15. I guess I lack listening intuition.

16. I believe listening tasks are the most difficult task among language skills.

17. No listening materials have aroused interest in me so far.

18. I dislike listening skill.

19. I believe too much time currently is spent on listening skill in language classes.

20. Listening is boring because I cannot keep following the speaker(s).

$\begin{array}{lllll}1 & 2 & 3 & 4 & 5 \\ 1 & 2 & 3 & 4 & 5 \\ 1 & 2 & 3 & 4 & 5 \\ 1 & 2 & 3 & 4 & 5 \\ 1 & 2 & 3 & 4 & 5 \\ 1 & 2 & 3 & 4 & 5 \\ 1 & 2 & 3 & 4 & 5 \\ 1 & 2 & 3 & 4 & 5 \\ 1 & 2 & 3 & 4 & 5 \\ 1 & 2 & 3 & 4 & 5 \\ 1 & 2 & 3 & 4 & 5 \\ 1 & 2 & 3 & 4 & 5 \\ 1 & 2 & 3 & 4 & 5 \\ 1 & 2 & 3 & 4 & 5 \\ 1 & 2 & 3 & 4 & 5 \\ 1 & 2 & 3 & 4 & 5 \\ 1 & 2 & 3 & 4 & 5 \\ 1 & 2 & 3 & 4 & 5 \\ 1 & 2 & 3 & 4 & 5 \\ 1 & 2 & 3 & 4 & 5\end{array}$

\section{Part C}

1. What are the characteristics of a good listener?

2. Please list the shortcomings of listening classes (if there is any). 